\title{
CROWN WIDTH-D.B.H. RELATIONSHIPS FOR OPEN- GROWN BALSAM FIR AND WHITE SPRUCE IN QUEBEC
}

\author{
By P. E. VEZINA ${ }^{1}$
}

ABSTRACT

Measurements of open-grown balsam fir and white spruce disclosed a high degree of correlation between width and d.b.h. for a given species. From this relation, Crown Competition Factor (CCF) values were applied to even-aged balsam fir stands of various ages and site indices, and related to other measures of stand density. These preliminary trials indicate that the CCF is a good measure to express the density of even-aged balsam fir stands, but its value will be further stressed if it can be successfully correlated with growth and yield.

\section{INTRODUCTION AND PURPOSE}

The dense even-aged stands of balsam fir and white spruce which develop in the Boreal forest region (Rowe 1959) following logging operations are a challenge to foresters. Advance growth is usually present (Hatcher 1960), and the site quality may be assessed (Linteau 1955). The only means at the forest manager's disposal to influence the future development and to enhance the productivity of these forest stands is control of stocking or density through some degree of cutting or thinning.

These conditions resulted in the establishment by a pulp company of partial cutting operations (Hatcher 1961) in young-mature balsam fir stands. Recently, the writer initiated thinning studies, and basic data are now being analysed to determine the relation of growth to stand density.

However, there appears to be no perfect measure of stand density; hence there is need for basic research on measurement of this variable (Bickford et al. 1957). The "Crown Competition Factor" concept of stand density reported by Krajicek and Brinkman (1957), and Krajicek et al., (1961) working in Iowa stimulated the writer to determine the d.b.h.-crown width relationships for open-grown balsam fir and white spruce. From data collected by the writer and furnished by other workers, the findings could be applied to balsam fir stands of various densities, ages, and site indices, and related to other measures of stand density.

\section{The "Crown Competition Factor" CONCePT}

Several investigators have determined excellent relations between an expression of crown measure and tree size (Ilvessalo 1950, Minor 1951, Wilson 1955, Gruschow and Evans 1959, Warrack 1959, and others). Among the most recent findings on crowns are the crown width to d.b.h. ratio and the crown width-to-top height ratio reported by Smith et al. (1961), and the Crown Competition Factor (CCF) reported by Krajicek et al. (1961). CCF is defined as the sum of Maximum Crown Area (MCA) values for all trees in a stand, divided by the area in acres. MCA is the percentage of an acre occupied by the

\footnotetext{
${ }^{1}$ Research Officer, Forest Research Branch, Department of Forestry, Quebec District Office, Sillery, P.Q.
} 
vertical projection of the crown of an open-grown tree. It is obtained by dividing the area of the crown in square feet by 435.6 .

Bickford et al. (1957) pointed out that "Crown closure and other expressions pertaining to crowns are relative to area occupation and are more properly indications of coverage than measures of stand density." According to Krajicek et al. (1961), CCF is not essentially a measure of crown closure, but is used as an expression of stand density, although it does pertain to crowns and is expressed in per cent. Theoretically, crown closure can occur from CCF 100 to the maximum for a given species (in balsam fir, it will be seen that it is approximately CCF 300 except for young stands). Rather than expressing crown closure, CCF reflects the area available to the average tree in the stand in relation to the maximum area it could use if it were open grown.

\section{MeTHODS}

To establish the relation between crown width and d.b.h. for opengrown trees, 199 open-grown trees were measured in a square area covering 200 square miles north of Quebec City: 53 balsam firs (Abies balsamea (L) Mill.) and 146 white spruce (Picea glauca (Moench) Voss). Only those trees that met the following specifications, given by Krajicek et al. (1961), wero included in the sample:

(a) crown free of competition on all sides;

(b) limbs extending to the ground or nearly so;

(c) lowest branches the longest, or at least as long as those above;

(d) no forking, no evidence of pruning or serious damage.

Balsam fir sample trees were found on cut-over areas and on road rightsof-way, whereas white spruce trees were found mostly in old fields.

The width of crown was determined at the height of maximum green width and was taken as the average of two measurements made at right angles by means of a tape ${ }^{2}$. The height of the maximum green width was at ground level except for larger trees. The observations were subjected to analysis by regression techniques (Ezekiel 1941).

Once the relation of crown width to d.b.h. for open-grown balsam fir was determined, the CCF values were calculated for 71 even-aged balsam fir stands of various site indices and ages. These plots had been established throughout the Boreal Forest Region in Quebec in the $1950^{\prime}{ }^{3}$. Plot size was 0.1 acre for young stands, and 0.2 acre for older ones. The stands analysed ranged from 30 years in age to 126 years. The stand density ranged from 105 to 227 square feet of basal area per acre, with average diameters from 2.3 to 9.0 inches. The site index at age 50 (Linteau 1955) for the various plots ranged from 35 to 57 feet.

- Simple devices for measuring crown width have been drawn by Nash (1948) and Brewer etal., (1959). The Nash scale was formerly used by the Forest Inventory Section, but proved to be somewhat inaccurate, particularly with small trees.

${ }^{3}$ Most of these unpublished data on which the computations are based werc furnished by $\mathrm{A}$. Linteau and G. J. Lemieux, District Forest Officer and Research Officer, respectively, Forest Research Branch, Department of Forestry, Quebec. 
As recommended by Krajicek et al. (1961), in each of the compilations of the CCF values, the number of trees in each d.b.h. class was used rather than the average diameter of the stand and the total number of trees. By this procedure, errors may be avoided, which could result from a diameter distribution deviating greatly from that of the normal curve.

Two other measures of stand density were computed for each plot. These were: basal area per acre, and Reineke's (1933) stand density index.

\section{RESUltS AND Discussion}

\section{Crown width-d.b.h. relations}

The relation between width of crown and d.b.h. is shown in Figure 1 for open-grown white spruce, and in Figure 2 for open-grown balsam fir. In these figures, the confidence bands refer to the line of the regression itself. Crown width and d.b.h. for both white spruce and balsam fir were highly correlated. The correlation coefficient $r$ is of the stame order of magnitude as those found by Krajicek et al. (1961) for other tree species. The difference between white spruce and balsam fir was statistically significant at the five per cent level. Significance of differences was also tested between balsam fir and Norway spruce and between white spruce and Norway spruce (the latter species had been studied by Krajicek et al. (1961). The differences botween Norway spruce and both white spruce and balsam fir were highly significant at the one per cent level (Table 1).

From the correlation analysis of the white spruce data (Fig. 1), tho maximum area that could be occupied by the crown of a white spruce of specified d.b.h. (D) was determined as follows:

$$
\mathrm{MCA}=\frac{\pi / 4(\mathrm{CW})^{2}}{435.60}=0.0018(\mathrm{CW})^{2}
$$

where

$$
\begin{aligned}
\mathrm{MCA}= & \text { "Maximum crown area" value of a tree with a crown diameter } \\
& \text { of } \mathrm{CW} . \\
\mathrm{CW} & =1.538 \mathrm{D}+3.2542^{4}
\end{aligned}
$$

and

$$
(\mathrm{CW})^{2}=2.365 \mathrm{D}^{2}+10.895 \mathrm{D}+12.546
$$

therefore

$$
\mathrm{MCA}=0.0043 \mathrm{D}^{2}+0.0196 \mathrm{D}+0.0226
$$

Similarly, the formula of MCA values for balsam fir (Fig. 2) was found to be:

$$
\mathrm{MCA}=0.0053 \mathrm{D}^{2}+0.02013 \mathrm{D}+0.0194
$$

- Another practical application of equations on Figs. 1 and 2 would be to estimate d.b.b. of open-grown balsam fir and white spruce from visible crown diameter as estimated from aerial photographs. If d.b.h. $(X)$ is estimated from crown width ( $Y$ ), then, the regressions become $X=0.581 Y-1.620$ for white spruce, and $X=0.55 Y-1.599$ for balsam fir. 
TABLE 1

Significance Of Differences Of The Correlation Coefficient ( $r$ ), The Regression Coefficient $\left(b_{y x}\right)$, ANd The Height Of The Sample RegresSion $\left(a_{y x}\right)$ For White Spruce, Balsam Fir, ANd Norway Spruce

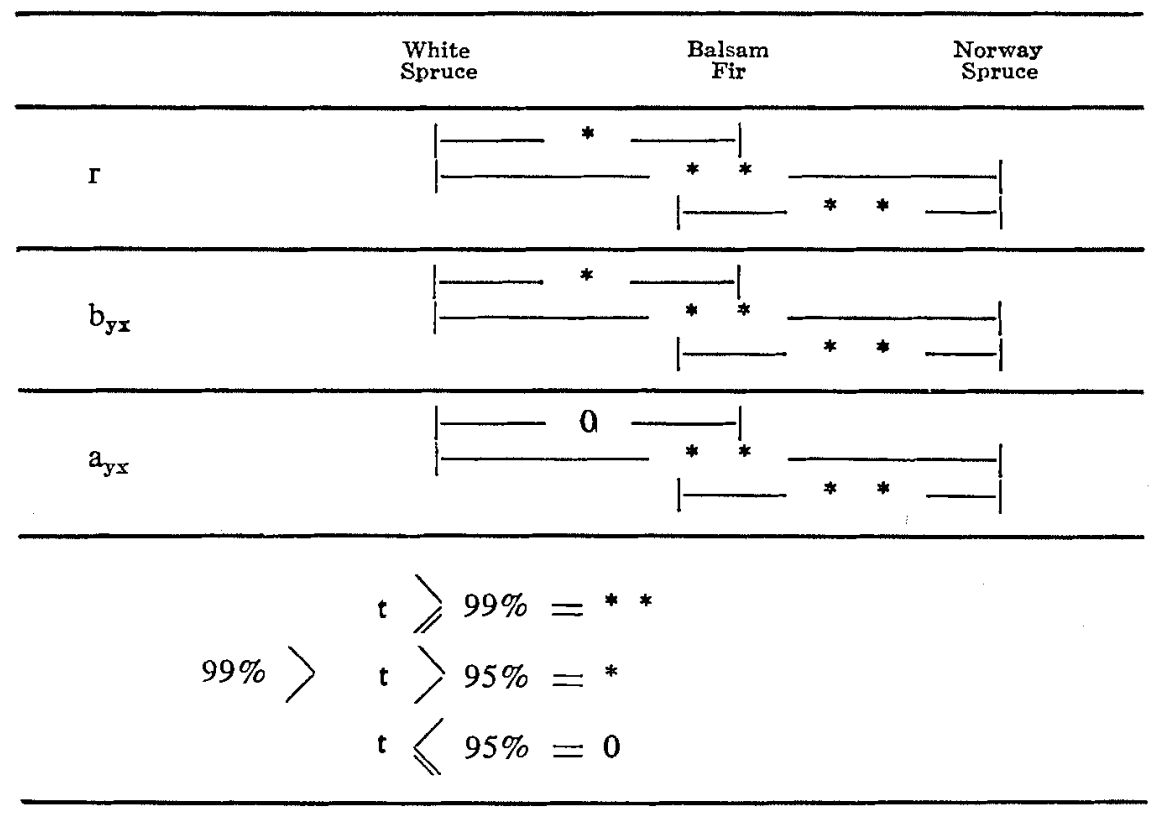

The MCA values allow the computation of the minimum number of open-grown white spruce and/or balsam fir that are theoretically required to produce a complete canopy (crown closure of 100 per cent). For instance, an open-grown balsam fir with d.b.h. of eight inches has a crown width of 17 feet (Fig. 2), or a crown area of 227 square feet ( 0.52 per cent of an acre). Thus, 192 open-grown balsam firs of that size could cover an acre completely $(0.52 \times 192=100$ per cent $)$. Other examples are given in Table 2 . According to number of trees or basal area per acre, a comparison of white spruce and balsam fir stands of the same density as measured by crown competition reveals little difference in their structure. It should be stressed that any combination of open-grown trees of various diameters whose MCA values total 100 for an acre could, theoretically, give a crown closure of 100 per cent.

\section{Application to even aged balsam fir stands}

The balsam fir formula was applied to stand data of each of the 71 plots in even-aged balsam fir (Table 3). These data are for fully stocked natural stands in the Boreal forest region. Yet the CCF values are consistent to a certain extent, except for high values in younger stands. This was also noted by Krajicek et al. (1961). 


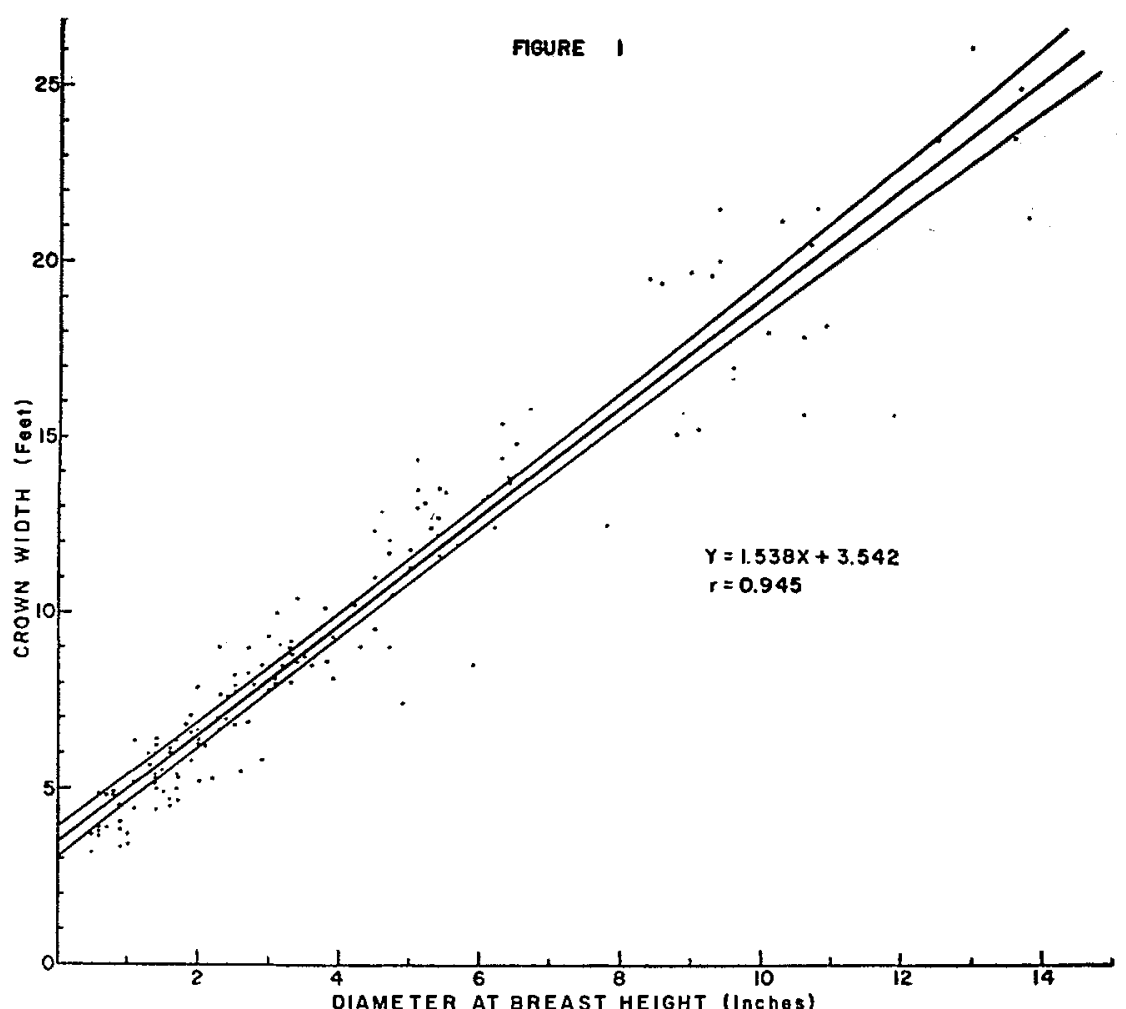

FIGURE 1. Relation of crown width to d.b.h. with confidence bands for 95 per cent level for open-grown white spruce. The bands refer to the line of the regression itself.

As the Crown Competition Factor is based strictly on tallies of diameter frequencies, it could yield similar competition figures for plantations and for strongly clumped natural stands. Yet competition in the latter type would be far more severe, tree by tree, than in the former. Fortunately, extremely clumped conditions are seen mostly on very poor sites where both balsam fir and white spruce are almost excluded.

According to Spurr (1952), the measure of density should be unrelated to age of the stand and quality of the site. To show this, scatter diagrams have been prepared which show the dependence of stand density as measured

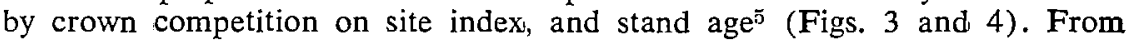
the diagrams, no strong relationship is evident between CCF and site index, but a probably significant decrease of CCF with age can be noted.

It should be pointed out that the belief that site has no influence in the maximum crown area (MCA) was not yet proved by direct measurement but by reference to plots - in Krajicek's study by reference to yield tables organized by site index and age classes. Table 3 , however, shows that $\Sigma$ MCA

\footnotetext{
${ }^{5}$ Basis 64 plots. Seven plots showing exceptionally high CCF values for younger stands have not been included in the diagrams.
} 
TABLE 2

Minimum Number Of Open-Grown Balsam Fir And White Spruce Of Specified D.B.H. On An Acre That Could Produce A 100 Per Cent Crows Closure

\begin{tabular}{ccc}
\hline D.b.h. & Balsam Fir & White Spruce \\
\hline Inches & $\begin{array}{c}\text { Number } \\
\text { Der acre }\end{array}$ & $\begin{array}{c}\text { Number } \\
\text { Der gere }\end{array}$ \\
\hline 1 & 2326 & 2222 \\
2 & 1235 & 1266 \\
3 & 787 & 847 \\
4 & 543 & 602 \\
5 & 398 & 442 \\
6 & 300 & 344 \\
7 & 237 & 271 \\
8 & 192 & 219 \\
9 & 157 & 183 \\
10 & 132 & 155 \\
11 & 112 & 132 \\
12 & 96 & 114 \\
13 & 84 & 100 \\
14 & 73 & 87 \\
\hline
\end{tabular}

TABLE 3

Application Of CCF To Stand Data (71 Plots) For Fully Stocked Natural Even-Aged Balsam Fir Stands. CCF By Age Class And Site: INDEX

\begin{tabular}{rrrrrr}
\hline $\begin{array}{c}\text { Age } \\
\text { (years) }\end{array}$ & 35 & 40 & $\begin{array}{c}\text { Site Index } \\
\text { (feet) } \\
45\end{array}$ & 50 & 55 \\
\hline 30 & 366 & 478 & 513 & - & - \\
40 & 311 & 379 & 277 & 323 & - \\
50 & - & 325 & 353 & 390 & 184 \\
60 & 338 & 301 & 278 & 246 & 209 \\
70 & 399 & 250 & 239 & 251 & - \\
80 & - & 285 & 202 & - & 311 \\
90 & - & 261 & 204 & - & - \\
100 & - & 283 & 273 & - & - \\
110 & - & 265 & - & - & - \\
120 & - & - & - & - & - \\
130 & - & 209 & 176 & - & - \\
\hline
\end{tabular}




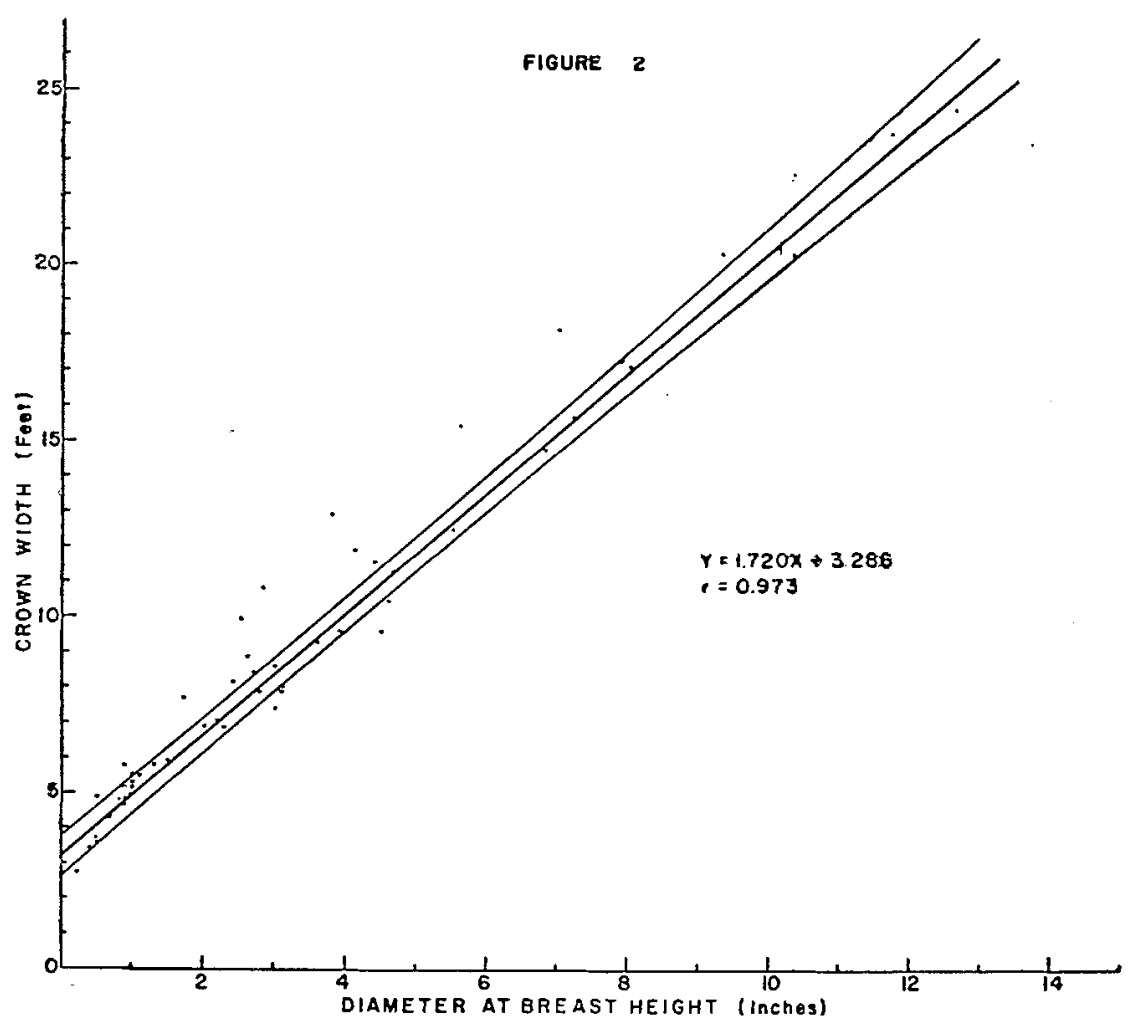

FIGURE 2. Relation of crown width to d.b.h. with confidence bands for 95 per cent level for open-grown balsam fir. The bands refer to the line of the regression itself.

in even-aged fully-stocked balsam fir stands varies somewhat: for instance, for site indices 40 and 45 from ages 30 to 130 , and for site indices 35 to 55 from ages 60 to 70 . Moreover, in view of the close correlation established between. MCA and d.b.h., the rather small variation in $\Sigma$ MCA for many combinations of age and height could simply mean that basal area is almost a constant for each class of Table 3 and this may in turn be an artifact introduced by the methods used in the construction of the table. The writer is aware of the difficulties which would be encountered in measuring directly site index where open-grown trees are likely to be found, but this should be done if the value of MCA and CCF is to be proved.

Comparison with other measures

It is of interest to compare CCF with other measures of stand density, that is, basal area (TBA) and Reineke's stand density index ${ }^{6}$ (SDI).

-The inder used here has been modified according to stand data recorded in the Boreal forest. The main curve now gives 1000 trees per acre for an average d.b.h. of six inches. 


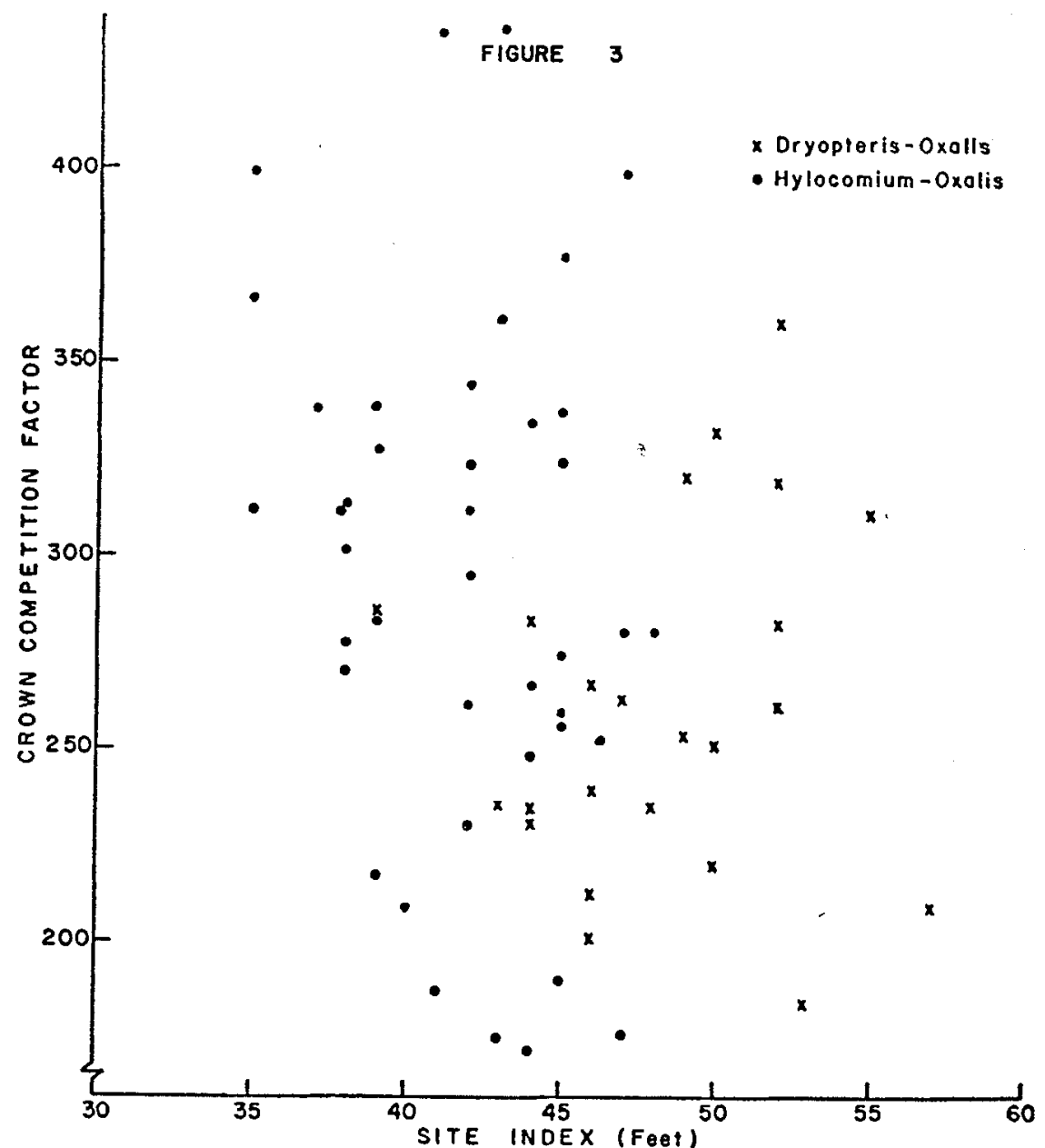

FIGURE 3. Scatter diagram relating stand density as measured by crown competition and site index.

The ratios of CCF values to TBA/CCF values for two site-types of balsam fir and for various average d.b.h. have been computed. The relationship between TBA/CCF and average stand d.b.h. is curvilinear (Fig. 5). Besides, the ratio of SDI values to TBA/SDI values for the same plots was found to be unaffected by stand d.b.h., and was equal to 0.51 . Thus, basal area multiplied by 0.51 equals the stand density index. From those regression lines it may be deduced that:

(1) CCF does not show a consistent relationship with stand density index. This was further shown by a scatter diagram relating SDI to CCF for the 


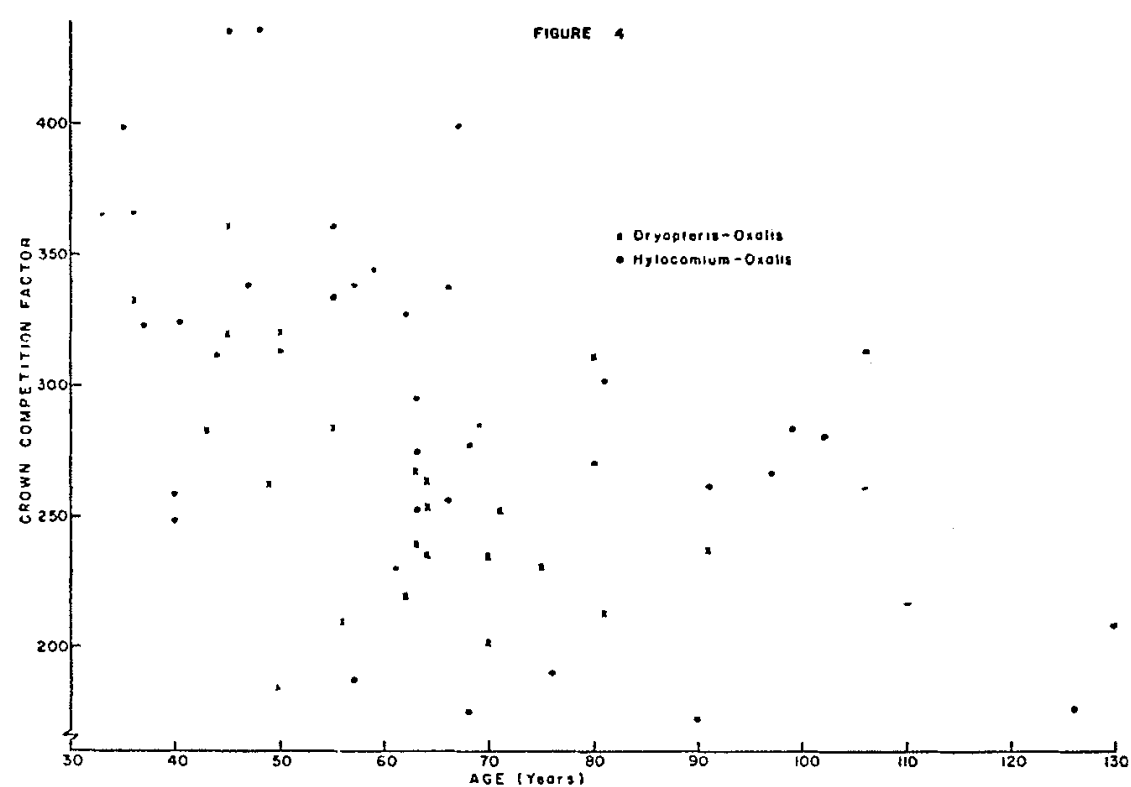

FIGURE 4. Scatter diagram relating CCF to age of stand.

71 plots considered. Plots having the same CCF could have different SDI, and vice-versa.

(2) The relationship between number of trees and average stand d.b.h. for any given CCF value is different from that between number of trees and average stand d.b.h. for any given SDI value. In fact, Krajicek et al. (1961) have shown that the latter is linear on logarithmic paper, whereas the former is curvilinear.

It should be pointed out, however, that these ratios are implicit in definitions used, and that they must be convertible from one another. A general example of relationships between average diameter, basal area, number of trees per acre, and crown width-d.b.h. ratios is given in Smith et al. 1961, p. 43. The $\mathrm{CW} / \mathrm{D}$ ratios there are a simplification and an extension of the basic ideas behind the CCF approach.

Conclusions

The results reported lead to the following conclusions:

(a) There exists a high correlation between d.b.h. and crown width for both white spruce and balsam fir.

(b) The regression between d.b.h. and crown width for open-grown balsam fir is statistically different from that for white spruce, at the five per cent level.

(c) The formula of CCF values for balsam fir stands is:

$$
\mathrm{CCF}=\frac{1}{\mathbf{A}}\left[0.0053\left(\Sigma \mathrm{D}_{\mathrm{i}}^{2} \mathrm{~N}_{\mathrm{i}}\right)+0.0203\left(\Sigma \mathrm{D}_{1} \mathrm{~N}_{1}\right)+0.0194\left(\Sigma \mathrm{N}_{1}\right)\right]
$$




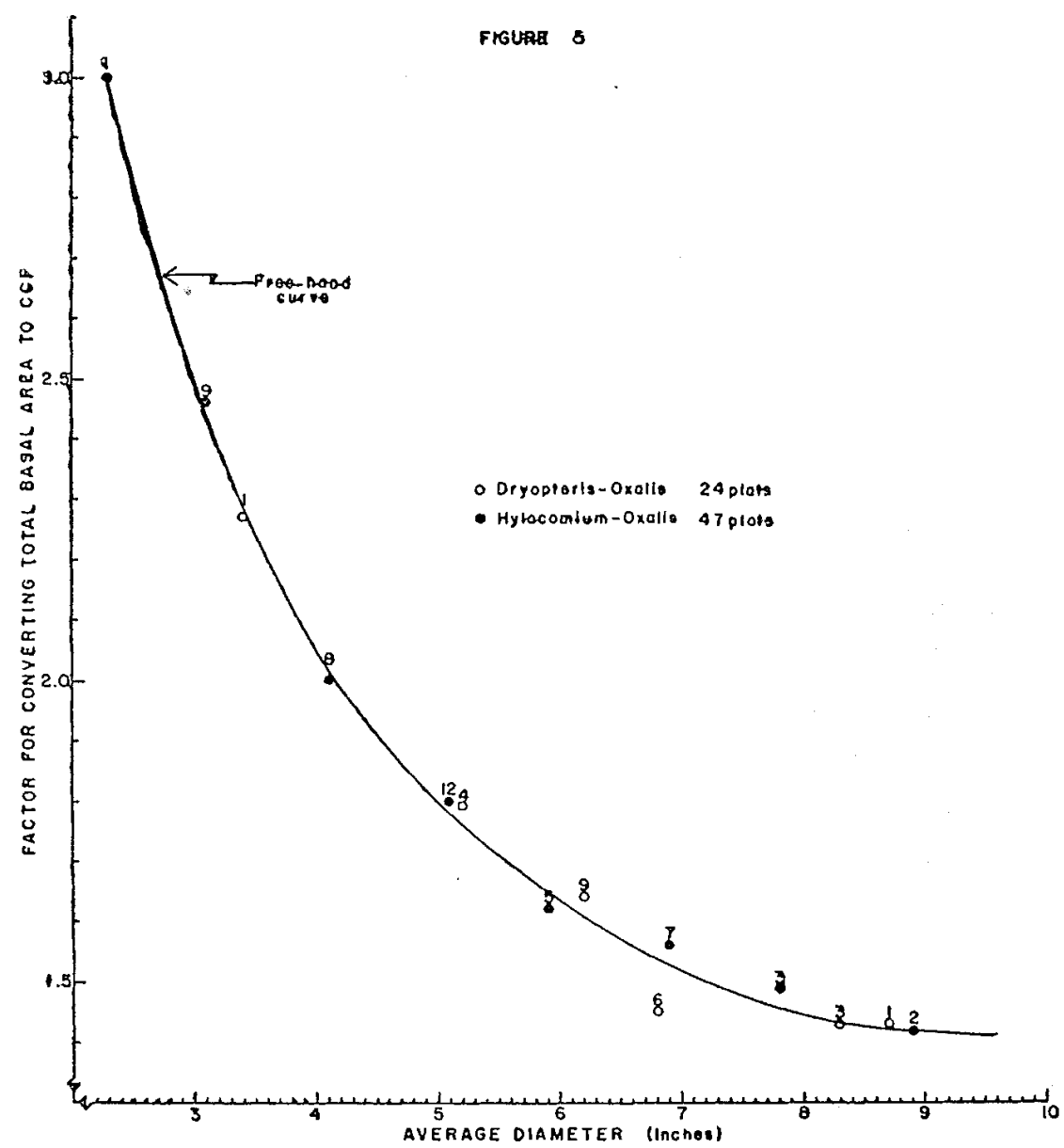

FIGURE s. Ratios of CCF volues to TBA/CCF values for two site-types of balsam fir and for various stand d.b.h. Figures on points represent number of plots. 
where $D_{1}=$ individual d.b.h. or d.b.b. class;

$N_{1}=$ number of trees in d.b.h. class;

$A=$ area in acres.

(d) For white spruce stands, it is:

$$
\mathrm{CCF}=\frac{1}{\mathrm{~A}}\left[0.0043\left(\Sigma \mathrm{D}_{\mathrm{i}}^{2} \mathrm{~N}_{\mathrm{i}}\right)+0.0196\left(\Sigma \mathrm{D}_{\mathrm{i}} \mathrm{N}_{1}\right)+0.0226\left(\Sigma \mathrm{N}_{\mathrm{i}}\right)\right]
$$

(e) Maximum CCF in balsam fir is approximately 300 , except for young stands.

(f) $\mathrm{CCF}$, as a measure of stand density, has been shown to vary somewhat with age of the stand and quality of the site.

(g) CCF does not show a consistent relationship with both basal area and stand density index.

\section{LiTERATURE}

BICKFORD, C. A., et al. 1957. Stocking, normality, and measurements of stand density. J. For. 55:99-104.

BREWER, L. C., et al. 1959. A device for measuring crown diameters of open-grown trees. J. For. 57:577.

EZEKIEL, M. 1941. Methods of correlation analysis. 2 nd ed. John Wiley and Sons, Inc., New York. 531 pp.

GRUSCHOW, G. F., and T. C. EVANS. 1959. The relation of cubic foot volume growth to stand density in young slash pine stands. For Sci. 5:49-55.

HATCHER, R. J. 1960. Development of balsam fir following a clear cut in Quebec. Canada, Dept. of North. Aff. and Nat. Res., For. Br., Tech. Note No. 87. 21 pp.

HATCHER, R. J. 1961. Partial cutting balsam fir stands on the Epaule River watershed, Quebec. Canada, Dept. of Forestry, Forest Research Branch, Tech. Note No. 105. 29 pp.

ILVESSALO, Y. 1950. On the correlation between the crown diameters and the stems of trees. Comm. Inst. For. Fenn. 38,2 (pp. 1-32 in reprint).

KRAJICEK, J. E., and K. A. BRINKMAN. 1957. Crown development: and index to stand density. Central States Forest Exp. Sta. Station Note No. 108.

KRAJICEK, J. E., and K. A. BRINKMAN. 1957. Crown development: an index to stand

LINTEAU, A. 1955. Forest site classification of the northeastern coniferous section, Boreal forest region, Quebec. Canada, Dept. of North. Aff. and Nat. Res., For. Br., Bull. No. 118. 85 pp.

MINOR, C. O. 1951. Stem crown-diameter relation in southern pine. J. For. 49:490-493.

NASH, A. J. 1948. The Nash scale for measuring tree crown widths. For. Chron. 24:117-120.

REINEKE, L. H. 1933. Perfecting a stand density index. J. Agr. Res, 46:627-638.

ROWE, J. S. 1959. Forest regions of Canada. Canada, Dept. of North. Aff. and Nat. Res., For. Br., Bull. No. 123. 71 pp.

SMITH, J. H. G., J. W. KER, and J. CSIZMAZIA. 1961. Economics of reforestation of Douglas fir, western hemlock, and western red cedar in the Vancouver Forest District. University of British Columbia. Faculty of Forestry, Forestry Bulletin No. 3. 144 pp.

SPURR, S. H. 1952. Forest inventory. Ronald Press, New York. 476 pp.

WARRACK, G. C. 1959. Crown dimension, initial diameter, and diameter growth in a juvenila stand of Douglas fir. For. Chron. 35:150-153.

WILSON, F. G. 1955. Evaluation of three thinnings at Star Lake. For. Sci. 1:227-231. 